European Health

Literacy Journal

\title{
FACTORS AFFECTING WOMEN'S PARTICIPATION IN GYNECOLOGICAL CANCER SCREENINGS
}

Ayca TOSUN ${ }^{1}$, Hakan DEMIRCl²

${ }^{1}$ Ulubatli Hasan Family Health Center, Bursa, TURKEY

2 Department of Family Medicine, University of Health Sciences Turkey Bursa Yuksek Ihtisas Training and Research Hospital, Bursa, TURKEY

\section{ABSTRACT}

Aim: The aim of this study was to investigate factors affecting the participation of women in gynecological cancer screening.

Methods: This study was conducted with female patients between ages 30-65 registered at the Bağlaraltı Family Health Center, affiliated with the Bursa provincial Public Health Directorate, between August 2018 and December 2018. It was performed with 214 female patients between ages 30-65 following evaluations of the patients registered with the Bağlaraltı Training FHC who did or did not participate in cancer screenings. A questionnaire examining sociodemographic, gynecologic and obstetric features of the female patients and the HL-EU-Q16 scale evaluating patients' health literacies were used in this research.

Results: From the results of our study, HL-EU-Q16 scale scores were found to be higher for participants who had a pap-smear test in compliance with the guidelines. $63 \%$ of the participants had breast cancer screening with mammography, whereas $19 \%$ underwent breast cancer screening in compliance with the guidelines. $36.90 \%$ did not have breast cancer screening with mammography. When asked about the reasons for not having this done, most of them answered as not finding it necessary, age factor or not being informed about the screening test. In this current study, factors affecting participation in mammography screening were found to be presence of chronic disease, breast self-examination and presence of suspicious lesions in previous tests. Another result of our study was that $70.50 \%$ of the participants underwent cervical cancer screening with a pap-smear test, whereas $11.70 \%$ of them had pap-smear screening in compliance with the guidelines. On the other hand, $29.40 \%$ did not have cervical cancer screening with a pap-smear test. When asked about the reasons for not having this done, most of them answered as not believing in its necessity, not being informed about it or thinking that they wouldn't have cervical cancer.

Conclusions: Pap-smear testing among gynecologic cancer screenings was found to be associated with women's health literacy. Having a mammogram was associated with the detection of a suspicious lesion in the past. Regular participation of patients in cancer screenings is limited. Regular examination in case of suspicious lesions or complaints was for diagnostic purposes rather than screening. Efforts must be exerted to make up the deficiency on this issue.

Keywords: gynecologic cancers, cancer screenings, mammography, breast cancer, health literacy, cervical cancer, pap-smear.

Corresponding Author: Ayca TOSUN ayca.tosun@saglik.gov.tr

Received: December 23, 2021; Accepted: December 29, 2021; Published Online: December 31, 2021

Cite this article as: Tosun, A. \& Demirci, H. (2021). Factors Affecting Women's Participation In Gynecological Cancer Screenings 1(3), 122-136. 



\section{Introduction}

According to the description made by World Health Organization (WHO), cancer is a group of diseases characterized by growth of cells uncontrollably as a result of genetic changes (1). Cancer is one of the most important and common problems of public health in Turkey, as well as all around the world (2). It is estimated that cancer, which comes after cardiovascular diseases among causes of death according to world cancer statistics, will take the first place as of 2030 with a rapid increase (3).

According to GLOBOCAN 2018 data, among females, breast cancer is the most commonly diagnosed cancer (4). Breast cancer is the most common cancer and the most common cause of mortality for women in Turkey (4). Breast cancer incidence increases with age. One in eight women have the risk of developing breast cancer in their lifetime. According to GLOBOCAN 2018 data, cervical cancer ranks fourth for incidence among women worldwide (4). In Turkey, cervical cancer is the $10^{\text {th }}$ leading cancer causing mortality in women (4). Cervical cancer screening is a screening that must be deemed important since cervical cancer is a disease that is preventable and $100 \%$ curable in case of early diagnosis and for which the pathogenesis has been clarified (5).

Early diagnosis and treatment are possible for some cancers by conducting appropriate programs, such as for breast and cervical cancers. According to current data in our country, most of the detected breast and cervical cancers are in stage III-IV. Within this context, it is of crucial importance to investigate problems on a national scale, develop national screening programs within the bounds of available opportunities and implement this throughout the country, considering regional differences (5). In efficient cancer control, palliation must be provided in the best way to allow all patients -with early or late diagnosis- to live a long and good quality life and have the best treatment of the disease. A national cancer control program protecting national resources and needs is essential to conduct these measures within a specific plan (5).

The aim of this study was to investigate the factors affecting women's participation in gynecological cancer screenings. There are studies showing that health literacy can also positively affect participation in gynecologic screening in addition to already recognized reasons for screening. For this reason, we also aimed to analyze the effect of health literacy on decisions of having a mammography or pap-smear.

\section{METHODS}

This study was conducted with female patients ages 30-65 registered with the Bağlaraltı Family Health Center, affiliated with Bursa provincial Public Health Directorate between August 2018-December 2018. The University of Health Sciences, Bursa Yuksek Intisas Training and Research Hospital approved the dissertation named "Factors Affecting People's Attendance in Gynecological Cancer Screenings" with the decision date 23.04.2018, no: 2011-KAEK-25.

The study was performed with 214 female volunteers between ages 30-65 registered with the Baglaralti Training FHC. Inclusion criteria for the participants were: being registered at the Baglaralti Training FHC, female patients of age 30-65 for pap-smear and female patients of age 40-65 for mammography, and accepting to participate in the research. This was a descriptive study. A face-to-face survey method was used in the study. Patients were informed before the survey and their consents were received. Patient confidentiality was respected.

A questionnaire interrogating the female patients' socio-demographic, gynecologic and obstetric features 
and the HL-EU-Q16 scale evaluating their health literacies were used in this research. The scale was a 5 point Likert type ranging from "(1) never" to "(5) always", and answers given to each question were scored between $0-4$. It consisted of 16 questions in total. Standardized index scoring was used in calculation of the total score obtained from the scale. The index score varied between 0-50, and health literacy $(\mathrm{HL})$ levels of the participants who received a score of 33 and higher were assessed as sufficient (6).

\section{Statistical Analysis}

Experimental power analysis was performed by considering the study's current results and by using a large effect size value ( $d \geq 0.5)$. Large effect size value (7) was obtained from the comparison of the general health literacy score of the HL-EU-Q16 scale between the groups who had a proper pap-smear test $(35.46 \pm 7.70)$ and who did not have a proper papsmear test $(31.12 \pm 5.14)$ and it was calculated as $d=0.66$. The power value obtained from the study was determined as $87 \%$ at the level of $a=0.05$, by using the related effect size, 25 in the group who had a proper pap-smear test and 189 in the group who did not have a proper pap-smear test, with a total of 214 units. Conformity of variables to normal distribution was analyzed with Shapiro Wilk test. Age and scores of the HL-EU-Q16 scale general and sub-scales were expressed with median (minimum: maximum) values. Categoric variables were expressed with $n(\%)$. Mann Whitney $U$ test was used in the inter-group comparisons of scores of the HL-EU-Q16 scale general and sub-scale scores. In case of sufficient and inadequate $\mathrm{HL}$ levels according to the related scores, chi-square test was used for comparisons among groups in terms of HL level. Logistic regression analysis was performed to inspect factors that could cause improper application of mammography and papsmear tests. Internal consistency of the HL-EU-Q16 scale general and sub-scales was analyzed using Cronbach alpha reliability coefficient. SPSS (IBM Corp. Released 2012. IBM SPSS Statistics for Windows, Version 21.0. Armonk, NY: IBM Corp.) program was used for statistical analysis and $p<0.05$ was accepted as statistically significant.

\section{RESULTS}

General characteristics of the participants are given in Table 1. Chronic diseases of the patients are given in Table 2. Obstetric and gynecologic characteristic of the participants are given in Table 3.

\section{Table 1: General characteristics of patients}

\begin{tabular}{|l|l|}
\hline & $\mathbf{n = 2 1 4}$ \\
\hline Age (years) & $49(33: 65)$ \\
\hline Education & \\
\hline Below high school & $165(77.10 \%)$ \\
\hline High school & $36(16.80 \%)$ \\
\hline Over high school & $13(6.10 \%)$ \\
\hline
\end{tabular}




\begin{tabular}{|c|c|}
\hline Marital Status & \\
\hline Married & $198(92.50 \%)$ \\
\hline Single & $4(1.90 \%)$ \\
\hline Divorced & $5(2.30 \%)$ \\
\hline Widow & $7(3.30 \%)$ \\
\hline \multicolumn{2}{|l|}{ Working Status } \\
\hline Housewife & $164(76.60 \%)$ \\
\hline Retired & $21(9.80 \%)$ \\
\hline Worker & $11(5.10 \%)$ \\
\hline Self-employment & $10(4.70 \%)$ \\
\hline Staff & $8(3.70 \%)$ \\
\hline Working & $29(13.60 \%)$ \\
\hline Not-working & $185(86.40 \%)$ \\
\hline \multicolumn{2}{|l|}{ Income } \\
\hline Good & $41(19.20 \%)$ \\
\hline Medium & $152(71 \%)$ \\
\hline Poor & $21(9.80 \%)$ \\
\hline Number of deliveries $^{\beta}$ & $3(0: 9)$ \\
\hline Body Mass Index ${ }^{Y}$ & 29.14(18:36:46.49) \\
\hline \multicolumn{2}{|l|}{ Smoking } \\
\hline Yes & $56(26.20 \%)$ \\
\hline No & $135(63.10 \%)$ \\
\hline Quit & $23(10.70 \%)$ \\
\hline Intrauterine device usage & $81(37.90 \%)$ \\
\hline Oral contraceptive usage & $13(6.10 \%)$ \\
\hline Cancer cases in family & $110(51.40 \%)$ \\
\hline
\end{tabular}

Data given as median (minimum: maximum) and $n$ (\%). $\beta$ : calculated over $n=206$ patients $\quad \gamma$ : calculated over $n=212$ patients 
Table 2: Distribution of chronic diseases

\begin{tabular}{|l|l|}
\hline Chronic Disease & $\mathbf{n = 2 1 4}$ \\
\hline Hypertension & $63(29.40 \%)$ \\
\hline Diabetes Mellitus & $33(15.40 \%)$ \\
\hline Cardiovascular Disease & $19(8.90 \%)$ \\
\hline COPD & $2(0.90 \%)$ \\
\hline Asthma & $16(7.50 \%)$ \\
\hline Hyperlipidemia & $11(5.10 \%)$ \\
\hline Cancer & $6(2.80 \%)$ \\
\hline Rheumatologic Disease & $7(3.30 \%)$ \\
\hline Depression & $6(2.80 \%)$ \\
\hline Others & $46(21.50 \%)$ \\
\hline Number of chronic diseases & $1(0: 6)$ \\
\hline
\end{tabular}

Data given as $n$ (\%) and median (minimum: maximum).

Table 3: Obstetric and gynecologic characteristics

\begin{tabular}{|l|l|}
\hline & $\mathbf{n = 2 1 4}$ \\
\hline Having Mammography & \\
\hline No & $79(36.90 \%)$ \\
\hline Once a year & $17(7.90 \%)$ \\
\hline Once every two years & $18(8.40 \%)$ \\
\hline Irregularly & $100(46.70 \%)$ \\
\hline Age of first mammography (year) ${ }^{\boldsymbol{\beta}}$ & $45(25: 58)$ \\
\hline Number of mammographies ${ }^{\boldsymbol{\gamma}}$ & $2(0: 20)$ \\
\hline Status of breast self-examination & \\
\hline
\end{tabular}




\begin{tabular}{|l|l|}
\hline Having Pap-smear & \\
\hline No & $63(29.40 \%)$ \\
\hline Once a year & $11(5.10 \%)$ \\
\hline Once every two years & $7(3.30 \%)$ \\
\hline Between 3-5 years & $7(3.30 \%)$ \\
\hline More than 5 years & $7(3.30 \%)$ \\
\hline Irregularly & $119(55.60 \%)$ \\
\hline Age of first Pap-smear (year) & \\
\hline Knowledge about Human papillomavirus & $41(18: 61)$ \\
\hline
\end{tabular}

Data given as median (minimum: maximum) and $n(\%)$. $\beta$ : calculated over $n=135$ patients. $\gamma$ : calculated over $n=136$ patients. $\delta$ : calculated over $n=212$ patients. $\varepsilon$ : calculated over $n=151$ patients

Reliability of the HLS-EU-Q16 scale of 16 questions was analyzed with Cronbach alpha (a) coefficient, and the study of Uzunsakal and Yildiz (8) was taken as reference in the interpretation of Cronbach alpha values (Table 4). Scale reliability was found to be "highly reliable" for general, "fairly reliable" for the Disease Treatment sub-scale, "low reliability" for Disease Prevention and "fairly reliable" for health promotion.

Table 4: Scores of health literacy scale, general and sub-scales and reliability coefficients

\begin{tabular}{|l|l|l|l|l|}
\hline \multirow{2}{*}{ HLS-EU-Q16 } & \multirow{2}{*}{ Score } & \multicolumn{2}{l|}{ HL Level } & Cronbach a \\
\cline { 4 - 5 } & & Sufficient & Inadequate & \\
\hline General & $30.21(20.83: 50)$ & $31.30 \%$ & $68.70 \%$ & 0.82 \\
\hline Health Care & $33.33(19.05: 50)$ & $51.40 \%$ & $48.60 \%$ & 0.70 \\
\hline Disease Prevention & $26.67(13.33: 50)$ & $29.90 \%$ & $70.10 \%$ & 0.58 \\
\hline Health Promotion & $33.33(16.67: 50)$ & $59.80 \%$ & $40.20 \%$ & 0.63 \\
\hline
\end{tabular}

Data given as median (minimum: maximum) and $n$ (\%).

Health literacy scores related to general and sub-scales did not differ among participants who did or did not have a proper mammography. Moreover, as a result of health literacy level determination according to the scale scores, no difference was detected in terms of the rate of patients with sufficient and inadequate health literacy levels among those who did or did not have a proper mammography (Table 5).

General health literacy scores did not differ in terms of status of having a pap-smear test. General scale score of the patients who had a proper pap-smear test was 
higher than those who did not have a proper test (Table 5).

When health literacy levels of the participants were classified as sufficient and inadequate in terms of general scale scores, a difference was detected in terms of this classification between the patients who did and did not have a proper pap-smear test. The rate of participants with sufficient health literacy was higher among those who had a pap-smear test (Table $5)$.

Health literacy scores of the treatment-service subscale did not differ among the participants who had or did not have a proper pap-smear test. There was also no difference between the participants who did or did not have a pap-smear test in terms of the rate of individuals with sufficient and inadequate health literacy levels, as a result of determination of health literacy levels according to the scale scores.
Scores of the disease prevention sub-scale, in terms of status of having a pap-smear test did not differ. Scale scores of participants who had a pap-smear test were higher than those who didn't have one (Table 5).

When health literacy levels of the participants were classified as sufficient and inadequate in terms of disease prevention sub-scale scores, a difference was detected in terms of this classification between those who did or did not have a pap-smear test. The rate of participants with a sufficient health literacy level was higher in the group who had a pap-smear test (Table $5)$.

Health promotion sub-scale scores did not differ in terms of status of having a pap-smear test. The scale score of participants who had a pap-smear test was higher than those who did not have one (Table 5).

Table 5: Relationship of health literacy (HL) with the status of having a mammography and pap-smear

\begin{tabular}{|c|c|c|c|}
\hline & Having Mammogr & & \\
\hline & Yes $(n=36)$ & No $(n=153)$ & \\
\hline General & $31.21(25: 43.75)$ & $30.21(20.83: 50)$ & $0.572^{\mathrm{a}}$ \\
\hline Sufficient HL & $13(36.10 \%)$ & $41(26.80 \%)$ & \\
\hline & $23(6390 \%)$ & & $0.266^{\mathrm{b}}$ \\
\hline Health Care & $33.33(21.43: 45.24)$ & $30.95(19.05: 50)$ & $0.654^{\mathrm{a}}$ \\
\hline Sufficient HL & $19(52.80 \%)$ & $73(47.70 \%)$ & \\
\hline & & & $0.584^{b}$ \\
\hline Inadequate $H L$ & $17(47.20 \%)$ & $80(52.30 \%)$ & \\
\hline Disease Prevention & $26.67(16.67: 43.33)$ & $26.67(13.33: 50)$ & $0.436^{a}$ \\
\hline Sufficient HL & $14(38.90 \%)$ & $38(24.80 \%)$ & \\
\hline Inadequate $\mathrm{HL}$ & $22(61.10 \%)$ & $115(75.20 \%)$ & \\
\hline
\end{tabular}




\begin{tabular}{|c|c|c|c|}
\hline Health promotion & $33.33(20.83: 50)$ & $33.33(16.67: 50)$ & $0.233^{\mathrm{a}}$ \\
\hline \multirow[t]{2}{*}{ Sufficient HL } & $23(63.90 \%)$ & $89(58.20 \%)$ & \multirow[b]{2}{*}{$0.530^{\mathrm{b}}$} \\
\hline & $13(\% 36,10)$ & $64(044180)$ & \\
\hline \multirow{3}{*}{ Inadequate $H L$} & \multicolumn{2}{|c|}{ Having Pap-smear } & \multirow{3}{*}{ p-value } \\
\hline & & \multirow{2}{*}{ No $(n=189)$} & \\
\hline & Yes $(n=25)$ & & \\
\hline General & $33.33(25: 50)$ & $30.21(20.83: 50)$ & $0.010^{a}$ \\
\hline \multirow[t]{2}{*}{ Sufficient HL } & $14(56 \%)$ & $53(285)$ & \multirow{3}{*}{$0.005^{b}$} \\
\hline & & & \\
\hline Inadequate $H L$ & $11(44 \%)$ & $136(72 \%)$ & \\
\hline Health Care & $33.33(23.81: 50)$ & $33.33(19.05: 50)$ & $0.148^{\mathrm{a}}$ \\
\hline \multirow[t]{2}{*}{ Sufficient HL } & $14(56 \%)$ & \multirow[t]{2}{*}{$96(50.80 \%)$} & \multirow{3}{*}{$0.625^{b}$} \\
\hline & & & \\
\hline Inadequate $H L$ & $11(44 \%)$ & $93(49.20 \%)$ & \\
\hline Disease Prevention & $33.33(20: 50)$ & 26.67(13.33:50) & $0.001^{a}$ \\
\hline \multirow[t]{2}{*}{ Sufficient HL } & $14(56 \%)$ & \multirow[t]{2}{*}{$50(26.50 \%)$} & \multirow{3}{*}{$0.002^{b}$} \\
\hline & & & \\
\hline Inadequate $H L$ & $11(44 \%)$ & $139(73.50 \%)$ & \\
\hline Health Promotion & $37.50(20.83: 50)$ & $33.33(16.67: 50)$ & $0.005^{a}$ \\
\hline \multirow[t]{2}{*}{ Sufficient HL } & $19(76 \%)$ & \multirow[t]{2}{*}{$109(57.70 \%)$} & \multirow{3}{*}{$0.079^{b}$} \\
\hline & & & \\
\hline Inadequate $H L$ & $6(24 \%)$ & $80(42.30 \%)$ & \\
\hline
\end{tabular}

Multi-variable logistic regression analysis was performed to determine the risk factors affecting not having a mammography. Variables of age, general, health care, disease prevention, health promotion, working status, education, income level, delivery status, presence of chronic disease, smoking status, cancer cases in the family, breast self-examination, suspicious lesion in a past test, application with neighbor, presence of symptoms and status of having proper cervical cancer screening in accordance with the guidelines were included as independent variables in this multi-variable logistic regression model. A forward selection strategy was adopted in the variable selection process and variables found in the regression model in the final step are given in Table 6. As a result of the analysis, the following findings were obtained (Table 6).

Risk of not having proper mammography decreases by $78 \%$ in case of chronic disease presence.

Risk of not having proper mammography decreases by $80 \%$ in those who perform breast self-examination.

Risk of not having proper mammography decreases by $88 \%$ in case of suspicious lesion in one's previous test. 
Risk of not having proper mammography is 15.49 times greater in those who do not have a proper papsmear test compared to those who did.

Multi-variable logistic regression analysis was performed to determine the risk factors affecting not having a proper pap-smear test. Variables of age, general, health care, disease prevention, health promotion, working status, education, income level, delivery status, presence of chronic disease, smoking status, cancer cases in the family, presence of symptoms and status of having proper breast cancer screening in accordance with the guidelines were included as independent variables in this multi-variable logistic regression model. A forward selection strategy was adopted in the variable selection process and variables found in the regression model in the final step are given in Table 6. As a result of the analysis, the following findings were obtained.

Risk of not having a proper pap-smear test decreases by $12 \%$ following a 1 unit increase in general $\mathrm{HL}$ score.

Risk of not having a proper pap-smear test is 10.49 times greater in those who did not have a proper mammography compared to those who did.

Table 6. Factors affecting risk of not having proper mammography and pap-smear test in accordance with the guidelines

\begin{tabular}{|c|c|c|c|c|c|}
\hline \multirow{2}{*}{ Factors for proper mammography } & \multirow{2}{*}{ Wald } & \multirow{2}{*}{$\begin{array}{l}\mathbf{p}- \\
\text { value }\end{array}$} & \multirow{2}{*}{ OR } & \multicolumn{2}{|c|}{$\begin{array}{l}\text { Confidence } \\
\text { Interval }\end{array}$} \\
\hline & & & & $\begin{array}{l}\text { Lower } \\
\text { Bound }\end{array}$ & $\begin{array}{l}\text { Upper } \\
\text { Bound }\end{array}$ \\
\hline \multicolumn{6}{|l|}{ Chronic Disease } \\
\hline None (Ref. Cat.) & - & - & 1 & - & - \\
\hline Yes & 5.91 & 0.015 & 0.22 & 0.06 & 0.75 \\
\hline \multicolumn{6}{|l|}{ Breast self-examination } \\
\hline None (Ref. Cat.) & - & - & 1 & - & - \\
\hline Yes & 6.88 & 0.009 & 0.20 & 0.06 & 0.66 \\
\hline \multicolumn{6}{|l|}{ Suspicious lesion in previous test } \\
\hline None (Ref. Cat.) & - & - & 1 & - & - \\
\hline Yes & 9.44 & 0.002 & 0.12 & 0.03 & 0.47 \\
\hline
\end{tabular}




\begin{tabular}{|c|c|c|c|c|c|c|}
\hline \multicolumn{7}{|l|}{ Proper pap-smear } \\
\hline None (Ref. Cat.) & - & - & 1 & & - & - \\
\hline Yes & 18.71 & $<0.001$ & \multicolumn{2}{|l|}{15.49} & 4.48 & 53.62 \\
\hline \multicolumn{7}{|l|}{ Model $X^{2}=75.67 ; \mathbf{p}<\mathbf{0 . 0 0 1}$} \\
\hline \multicolumn{7}{|l|}{ Pseudo $\mathrm{R}^{2}=\% 58$} \\
\hline \multicolumn{7}{|l|}{$n=214$} \\
\hline \multirow[b]{2}{*}{ Factors for proper pap-smear } & \multirow[b]{2}{*}{ Wald } & \multirow{2}{*}{$\begin{array}{l}\text { p- } \\
\text { value }\end{array}$} & \multirow[b]{2}{*}{ OR } & \multicolumn{3}{|c|}{ Confidence Interval } \\
\hline & & & & $\begin{array}{l}\text { Lower } \\
\text { Bound }\end{array}$ & Lowe & er Bound \\
\hline General HL score & 6.87 & 0.009 & 0.88 & 0.80 & 0.97 & \\
\hline \multicolumn{7}{|c|}{ Proper breast cancer screening according to the guidelines } \\
\hline None (Ref. Cat.) & - & - & 1 & - & - & \\
\hline Yes & $\mid 17.99$ & $<0.001$ & 10.49 & 3.54 & 31.09 & \\
\hline \multicolumn{7}{|l|}{ Model $X^{2}=28.87 ; \mathbf{p}<\mathbf{0 . 0 0 1}$} \\
\hline \multicolumn{7}{|l|}{ Pseudo $\mathrm{R}^{2}=\% 33$} \\
\hline $\mathrm{n}=214$ & & & & & & \\
\hline
\end{tabular}

OR: Odds ratio, Ref. cat.: Reference category

General HL score of participants who voluntarily had a pap-smear test was found to be higher than those who did not. There was no difference in terms of $\mathrm{HL}$ score according to the other comparisons given in Table 7.

Table 7. Information source of pap-smear test and health literacy (HL) score correlation

\begin{tabular}{|l|l|l|}
\hline Source of information & HL Score & p-value \\
\hline Doctor & & \\
\hline Yes $(n=102)$ & $30.21(20.83: 50)$ & $0.574^{\mathrm{a}}$ \\
\hline No $(n=51)$ & $30.21(22.92: 50)$ & \\
\hline Midwife/nurse & $30.21(20.04: 50)$ & $0.449^{\mathrm{a}}$ \\
\hline Yes $(n=36)$ & $31.25(20.83: 50)$ & \\
\hline No $(n=117)$ & & \\
\hline
\end{tabular}




\begin{tabular}{|l|l|l|}
\hline Family & & \\
\hline Yes $(n=3)$ & $34.38(27.08: 38.54)$ & \\
\hline No $(n=150)$ & $30.21(20.83: 50)$ & \\
\hline Friend & $30.73(22.92: 41.67)$ & $0.585^{\mathrm{a}}$ \\
\hline Yes $(n=14)$ & $30.21(20.83: 50)$ & \\
\hline Media $(n=139)$ & $32.92(27.08: 36.46)$ & \\
\hline Yes $(n=7)$ & $30.21(20.83: 50)$ & $0.512^{\mathrm{a}}$ \\
\hline No $(n=146)$ & & \\
\hline Self-decision & $32.32(25: 42.71)$ & $\mathbf{0 . 0 3 3 ^ { \mathrm { a } }}$ \\
\hline Yes $(n=27)$ & $30.21(20.83: 50)$ & \\
\hline No $(n=124)$ & & \\
\hline
\end{tabular}

Data given as median (minimum: maximum) and $n$ (\%). *: As unit number of "yes" group under family variable wasn't sufficient, statistical analysis couldn't be made. a: Mann Whitney $\cup$ Test.

\section{DISCUSSION}

From the results of our study, the HL-EU-Q16 scale score of participants who had a pap-smear test in accordance with the guidelines was found to be high. $63 \%$ of participants had breast cancer screening with mammography and $19 \%$ of them had an accurate breast cancer screening in accordance with the guidelines. $36.90 \%$ did not have breast cancer screening with mammography. When they were asked about the reasons for not having breast cancer screening, the majority of them answered that they didn't find it necessary, age factor or that they were not informed about screening tests. In this current study, factors affecting mammography screening were detected as presence of chronic disease, breast selfexamination and suspicious lesion in the previous test. Whereas $70.50 \%$ of our participants had cervical cancer screening with a pap-smear test, $11.70 \%$ had an accurate pap-smear screening in accordance with the guidelines. On the other hand, $29.40 \%$ of them did not have cervical cancer screening with a pap-smear test. When they were asked about the reasons for not having cervical cancer screening, the majority of them answered that they didn't find it necessary, they weren't informed about it or they thought they wouldn't develop cervical cancer.

In our study, health literacy scores of general and subscales did not differ between the participants who did or did not have a mammography. There is no study in Turkey on the effect of health literacy on gynecologic cancer screening. According to a study conducted in New York, the possibility of women with inadequate functional health literacy in Spanish (when compared with women with sufficient health literacy) to have a pap-smear was lower, following the adjustments for their education and years in the United States of America, source of treatment, status of health 
insurance and age (9). In another study conducted with female patients from different ethnic origins in Chicago, it was detected that health literacy had much more effect on participation in screenings compared to educational level and ethnic origin (10). In a study performed with Mexican American women over age 40 in Texas, women with high health literacy presented a higher rate of mammography screening testing (11). In our study, whereas $\mathrm{HL}$ scale was not associated with mammography, it was found to be associated with pap-smear. The reason for this situation can be argued as the age of our participants being between 30-65, cultural differences, ethnic origin, easy access to pap-smear tests and mammography. The reason that health literacy did not differ in mammography tests but differed in pap-smear tests makes us think that it also affects pap-smear results. Transfer of the patients to the hospital who had screening tests and whose results were suspicious, and follow-up of the patients with colposcopy and conization can lead to an increase in health literacy. On the other hand, followup of patients with mammography in case of suspicious results of mammography tests may not have affected health literacy.

The Bursa province, Yildirim region, is a migrationreceiving region from the east. The educational level of $77.10 \%$ of the patients who had screenings was below high school. As a result of our study, $63 \%$ of the participants had breast cancer screening with mammography at least once in their lifetime. Only $19 \%$ of the participants underwent screening with proper mammography in accordance with the screening procedure within the national cancer program. In the study of Moskowitz et al. (12), the rate of having mammography was detected as $67.8 \%$; this rate was $53 \%$ in the study of Coates et al. (13); $52 \%$ in the study of Soskolne et al. (14). The mammography rate was $65.5 \%$ in a study performed by Ozaydin et al. in Istanbul by Bahcesehir (15). In another study conducted in Ordu by Ugur et al., $44.3 \%$ of the women, in the study of Yucel et al. in Afyon $53 \%$ of the women, in the study of Maral et al. in Ankara $20.3 \%$ of the women in rural areas indicated that they underwent mammography for breast cancer screening (16-18). Although our study results on the rate of mammography screening testing resemble the results of the study of Ozaydin et al., they are higher than other studies. This situation suggests that urban region, easy access to family medicine and presence of a hospital in the region can facilitate screenings. Cancer case in the family, family-friend factor, total participation in cancer screenings and detection of a suspicious lump in breast self examination can be factors affecting screening. Whereas the mammography rate was $57.2 \%$ in a study in Izmir Bornova, the rate of proper mammography was to be $18.5 \%$ (19). In the study of Discigil et al, conducted in the Western Aegean region in 2007, they found that $40.6 \%$ of the women had mammography and nearly half of them had it regularly with appropriate intervals (20). Considering these studies, mammography rates in our study were similar. This situation could be caused by the low educational level of our participants.

When they were asked about the reasons for not having a mammography, the majority of them answered that they didn't find it necessary (40.00\%). This response was followed by being below age 40 $(24.44 \%)$, not knowing about the issue $(10.00 \%)$, not being at risk (8.89\%), lack of time (5.56\%) and being afraid of the results (4.44\%). Rizalar et al. and Meissner et al. also reported in their studies that the reason for not having a mammography was lack of information $(21,22)$.

$70.50 \%$ of the participants had cervical cancer screening with a pap-smear test at least once in their lifetime. $11.70 \%$ of them had screening with a proper pap-smear test within the context of the national 
cancer program screening procedure. It was detected that $78.9 \%$ of women of age group 25-49 in England regularly had cervical cancer screening (23). Cervical cancer screening rates vary from $75 \%-95 \%$ in most European countries (24). According to the study performed in Izmir Bornova, $41.0 \%$ of women had cervical cancer screening with the recommended screening frequency (19). This rate was $46.2 \%$ in another study in the same region by Acikgöz et al. (25). Akyuz et al. found the rate of two and more cervical cancer screenings as $41.8 \%$ (26). Considering these rates, although rates of having a pap-smear were high in our study, rates of having a proper papsmear were very low. This situation can be explained by low educational level, low awareness level of cancer screening programs, not seeing themselves under risk and discomfort caused by gynecologic examination.

Participants who underwent a pap-smear test were asked about the source of information on pap-smear tests and responses were respectively: doctor $(63.35 \%)$, midwife-nurse $(21.74 \%)$, friend $(8.70 \%)$, media (4.35\%) and family (1.86\%). In the study of Ak et al., it was detected that women got information on gynecologic cancers from health institutions (57.0\%), and according to the study of Gumus and Cam, the information source was medical personnel (45.7\%). Esencan reported in his study that information sources for women on gynecologic cancers were doctors $(21.7 \%)$ and nurses (11.5\%) (27-29). The fact that the most common source of information for pap-smear participation is doctors according to our study, could be caused by the patients' admission to specific branches other than family medicine with their symptomatic complaints and they could have had screening with the medical recommendation in these branches. Even though the second source was midwife-nurse, the rate was low. This situation can be caused by the working conditions of nurses and because they don't practice actively in outpatient clinics. Moreover, if these screenings are performed with symptoms, this means that pap-smear tests are used as diagnostic tests rather than screening tests. If so, healthcare personnel other than medical staff who give secondary importance to the smear test, and also the media, will have a larger responsibility. It is hoped to have higher test participation even without symptoms so that the test will gain functionality as a screening test.

In conclusion, women's status of having a pap-smear was one of the gynecologic cancer screenings found to be associated with health literacy. Mammography screening was previously associated with detection of suspicious lesions. Regular participation of patients in cancer screening is limited. Regular examination in case of suspicious lesions or complaints is for diagnostic purposes rather than screening. Efforts must be exerted to address the deficiency on this issue.

\section{CONFLICT OF INTEREST}

The authors declare that there is no conflict of interest. 


\section{References}

1. IARC Working Group on the Evaluation of Carcinogenic Risks to Humans, World Health Organization, \& International Agency for Research on Cancer. Tobacco smoke and involuntary smoking (No. 83). larc. 2004.

2. Karayurt $\mathrm{O}$, Ozmen $\mathrm{D}$, Cetinkaya AC. Awareness of breast cancer risk factors and practice of breast self examination among high school students in Turkey. BMC public health, 2008; 8(1): 1-8.

3. Mathers, C. D., \& Loncar, D. Projections of global mortality and burden of disease from 2002 to 2030. PLoS medicine. 2006; 3(11): e442.

4. Cumberbatch MGK, Jubber I, Black PC, et al. Epidemiology of bladder cancer: a systematic review and contemporary update of risk factors in 2018. European urology. 2018; 74(6): 784-795.

5. Lowy, I. A woman's disease: the history of cervical cancer. OUP Oxford. 2011.

6. Emiral G, Tozun M., Atalay B, et al. Assessment of knowledge of metabolic syndrome and health literacy level among adults in Western Turkey. Nigerian Journal of Clinical Practice. 2021; 24(1): 28-28.

7. Sullivan GM, Feinn R. Using effect size-or why the $P$ value is not enough. Journal of graduate medical education. 2012: 4(3): 279282

8. Uzunsakal E, Yildiz D. Alan araştirmalarinda güvenilirlik testlerinin karşilaştirilmasi ve tarimsal veriler üzerine bir uygulama. Uygulamalı Sosyal Bilimler Dergisi. 2018; 2(1): 14-28.

9. Carrasquillo O, Pati $S$. The role of health insurance on Pap smear and mammography utilization by immigrants living in the United States. Preventive Medicine. 2004; 39(5): 943950.

10. Lindau ST, Basu A, Leitsch SA. Health literacy as a predictor of follow-up after an abnormal pap smear. Journal of general internal medicine. 2006; 21(8): 829-834.

11. Lopez-McKee G. Development of the mammography beliefs and attitudes questionnaire for low-health-literacy Mexican-American women. The Online Journal of issues in Nursing. 2010; 16(1).

12. Moskowitz JM, Kazinets G, Wong JM, Tager IB. "Health is strength": A community health education program to improve breast and cervical cancer screening among Korean American Women in Alameda County, California. Cancer Detection and Prevention. 2007; 31(2): 173-183.

13. Sabatino SA, Coates RJ, Uhler RJ, Alley LG, Pollack LA. Health insurance coverage and cost barriers to needed medical care among US adult cancer survivors age $<65$ years. Cancer. 2006; 106(11): 2466-2475.

14. Soskolne V, Marie S, Manor O. Beliefs, recommendations and intentions are important explanatory factors of mammography screening behavior among Muslim Arab women in Israel. Health education research. 2007; 22(5): 665-676.

15. Ozaydin A. N., Gulluoglu BM, Unalan PC, Gorpe S, Cabioğlu N, Oner BR, Ozmen V. BAHÇEŞEHIR'DE OTURAN KADINLARIN MEME KANSERI BILGI DÜZEYLERI, BILGI KAYNAKLARI VE MEME SAĞLIĞı ILE ILGGLI UYGULAMALARI. Meme Sagligi Dergisi/Journal of Breast Health. 2009; 5(4).

16. Ugur HG, Avci IA. (2015). Kanser tarama merkezine başvuran kadınların sağlıklı yaşam biçimi davranışlarının erken tanı bilgi ve uygulamalarına etkisi. Gümüşhane Üniversitesi Sağlık Bilimleri Dergisi. 2015; 4(2): 244-258.

17. Yucel A, Degirmenci $B$, Acar $M$, Ellidokuz $H$, Albayrak R, Haktanir A. Knowledge about breast cancer and mammography in breast cancer screening among women awaiting mammography. Turkish Journal of Medical Sciences. 2005;35 (1):35-42.

18. Maral I, Budakoglu II, Ozdemir A, Bumin MA. Behaviors toward methods of breast cancer early detection in women over 40 years in a rural region of Ankara, Turkey. Journal of Cancer Education. 2009;24 (2):127-8.

19. Gunvar T, Cinar A. İzmir İli Bornova İlçesindeki 55 Yaş Üstü Kadınların Kanser Taraması Yaptırma Davranışı Ve Bu Davranışın Birinci Basamak Sağılık Hizmetleri Kullanımı Ille İlişkisi, İzmir 2016.

20. Discigil, G., Sensoy, N., Tekin, N., Soylemez, A. Breast health: knowledge, behaviour and performance in a group of women living in the Aegean region. Marmara Medical Journal. 2007; 20(1): 29-36.

21. Rizalar S, Altay B. Early Diagnosis Applications of Women with Breast Cancer. Firat Saglık Hizmetleri Dergisi 2010; 5: 73-87. 
22. Meissner $\mathrm{HI}$, Breen N, Taubman ML, Vernon SW, Graubard BI. Which women aren't getting mammograms and why? (United States). Cancer Cause Control 2007; 18:61-70.

23. Patnick J. NHS Cervical Screening Programme Annual Review 2011. NHS Cancer Screening Programmes. 2012:1-24.

24. Anttila A, Ronco G, Clifford G, Bray F, Hakama $M$, Arbyn $M$, et al. Cervical cancer screening programmes and policies in 18 European countries. British journal of cancer. 2004;91 (5):935-41

25. Acikgoz A, Cehreli R, Ellidokuz H. Kadınların Kanser Konusunda Bilgi ve Tutumları ile Erken Tanı Yöntemlerine Yönelik Davranışları. 2011.DEU Tıp Fakültesi Dergisi.25 (3)

26. Akyuz A, Guvenc G, Yavan T, Cetinturk A, Kok G. Kadınların Pap smear yaptırma durumları ile bunu etkileyen faktörlerin belirlenmesi. Gülhane Tıp Dergisi. 2006;48 (1):25- 29.

27. Ak M, Canbal M, Turan S, Gürbüz N. Aile Hekimliği Polikliniğine Başvuran Kadınlarda Papsmear Testinin Farkındalı̆ı̆ının Değerlendirilmesi, Konuralp Tıp Dergisi. 2009; 2(2): 1-4.

28. Gumus A, Cam O. Kadınların Serviks Kanseri İçin Erken Tanı Tutumları İle Benlik Saygısı, Beden Algısı Ve Umutsuzluk Düzeyleri Arasındaki İlişkiler. Nobel Med. 2011: 7(3): 4652.

29. Esencan T. Jinekolojik Erken Tanı Yöntemlerinin Kullanımında Kadınların Tutum ve Davranışlarının Değerlendirilmesi. Zeynep Kamil Tıp Bülteni. 2009; 40 (2). 